\section{luz ribeiro}

29 anos, nascida no verão de são paulo é coletiva: poetas ambulantes, slam do 13, legítima defesa e slam das minas-sp. autora dos livros eterno contínuo (2013), espanca (2017) e estanca (2017), possui textos autorais em diversas antologias. campeã do "slam br - 2016" (batalha nacional de poesia falada). luz gosta de escrever com letrinha minúscula. queria voar, mas é concreta demais pra planar e carrega ondas na caixa torácica, é a mar nas vielas, se vê poeta bruta, e pra não embrutecer, mais.

\section{jene parle pasbien}

excuse moi, pardon

me...

je ne parle pas bien français

je ne parle pas bien anglais non plus

je ne parle pas bien

je ne parle pas bien

je ne parle pas bien

je ne parle pas bien

eu tenho uma língua solta que não me deixa esquecer

que cada palavra minha

é resquício da colonização

cada verbo que aprendi conjugar

foi ensinado com a missão

de me afastar de quem veio antes

nossas escolas não nos ensinam

a dar voos, subentendem que nós retintos ainda temos grilhões nos pés

esse meu português truncado

faz soar em meus ouvidos

o lançar dos chicotes

em costas de couros pretos 


\section{opiniães}

nos terreiros de umbanda

evocam liberdade e entidade

com esse idioma que tentou nos prender

cada sílaba separada

me faz relembrar

de como fomos e somos segregados

nos encostaram nas margens

devido a uma falsa abolição

que nos transformou em bordas

me...

je ne parle pas bien

je ne parle pas bien

tiraram de nós o acesso

a ascensão

e eis que na beira da beira, ressurgimos

reinvenção

nossa revolução surge e urge

das nossas bocas

das falas aprendidas

que são ensinadas

e muitas não compreendidas

salve, a cada gíria je ne parle pas bien

temos funk e blues

de baltimore a heliopólis

com todo respeito edith piaf

não é você quem toca no meu set list

eu tenho dançado ao som de "coller la petite"

je ne parle pas bien

o que era pra ser arma de colonizador

está virando revide de ex colonizado

estamos aprendendo as suas línguas

e descolonizando os pensamento

estamos reescrevendo o futuro da história

não me peçam pra falar bem

parce que je ne parle pas bien

je ne parle pas bien

je ne parle pas bien, rien

eu não falo bem de nada

que vocês me ensinaram

[POEMA INÉDITO]

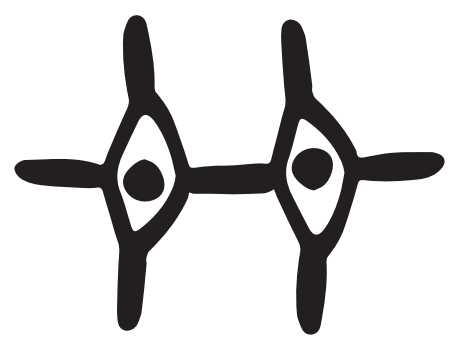

